\title{
Belgeo
}

Revue belge de géographie

$1 \mid 2007$

The advanced service sectors in European urban regions

\section{Russian regional capitals as new international actors: the case of Yekaterinburg and Rostov}

Les capitales régionales russes, nouveaux acteurs internationaux : le cas de Yekaterinburg et Rostov

\section{Vladimir Kolossov and Denis Eckert}

\section{(2) OpenEdition}

\section{Journals}

\section{Electronic version}

URL: http://journals.openedition.org/belgeo/11686

DOI: 10.4000/belgeo.11686

ISSN: 2294-9135

\section{Publisher:}

National Committee of Geography of Belgium, Société Royale Belge de Géographie

\section{Printed version}

Date of publication: 1 January 2007

Number of pages: 115-132

ISSN: 1377-2368

Electronic reference

Vladimir Kolossov and Denis Eckert, «Russian regional capitals as new international actors: the case of Yekaterinburg and Rostov », Belgeo [Online], 1 | 2007, Online since 09 December 2013, connection on 19 April 2019. URL : http://journals.openedition.org/belgeo/11686; DOI : 10.4000/belgeo.11686

This text was automatically generated on 19 April 2019

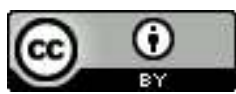

Belgeo est mis à disposition selon les termes de la licence Creative Commons Attribution 4.0 International. 


\title{
Russian regional capitals as new international actors: the case of Yekaterinburg and Rostov
}

\author{
Les capitales régionales russes, nouveaux acteurs internationaux : le cas de \\ Yekaterinburg et Rostov
}

Vladimir Kolossov and Denis Eckert

\section{Inroduction}

1 Russia, which for over 75 years had developed as part of an isolated, self-sufficient Soviet state and society, since 1991 has been undergoing a difficult process of adaptation to the realities of an open and globalised world. The process of becoming integrated into the world economy has affected the different parts of Russian territory in very diverse ways. The transition to an open and liberal economy has resulted, in particular, in the formation of a highly polarised spatial structure, in which the main cities have gained a privileged position. Russia has 13 cities with populations in the millions (including Moscow and Petersburg), accounting for $20 \%$ of the entire population (Census 2002). This well-developed metropolitan system emerged within the quite specific context of the centralised Soviet system, in a period characterised by booming urban growth. In the first post-Soviet decade, some of these cities benefited from the relative decline of the influence of the centralised state, at the same time that the regions (which became "subjects of the Federation") have become the major political actors at the sub-federal scale.

2 Many scholars have emphasised the fact that Moscow, in particular, became rapidly integrated into the world-city system, concentrating wealth and monopolising intermediate functions between Russia and the rest of the world economy. The capital is by far the most significant node of financial flows in the country (Kolossov and Vendina, 1997; O'Loughlin and Kolossov, 2002; Kolossov and O'Loughlin, 2004; Eckert, 2004), and its 
contribution to national GDP doubled between 1994 (10,2\%) and 2004 (19,0\%). In a wellknown classification of world cities, promoted at the end of the 1990s by a group of scholars (Beaverstock, Smith and Taylor, 1999; Taylor, 2000), and based on the importance of a given set of international corporate services, Moscow received the highest rank among all post-socialist cities in Central and Eastern Europe. Taylor and Hoyler, in particular (2000), in studying the main 53 European cities, included Moscow in the "beta" cluster of Europe's world cities, i.e. immediately after the leading "alpha" group (London, Paris, Frankfurt, Milan) and far ahead of Saint Petersburg and Kiev, the only cities of the former Soviet Union included in the ranking.

But how have the other big metropolises managed? Did 11 other major cities follow Moscow - and Petersburg - along the same path? Did they place well in the growing competition between territorial units to attract key resources - information, technologies, capital, labour - in order to guarantee their economic and social development, as defined by Harvey (1989)? Are they becoming a part of the post-Westphalian international system that has allegedly arisen, a system in which major urban regions are called upon to play a growing role (Scott, 2000), organising economic and cultural flows in the context of the supposed decline of centralised states, and do they develop their own specific policy on relations with foreign economic and political actors, in the way Western European cities have gradually been doing, as emphasised by P. Le Galès (2002)? Is it possible to apply to regional cities the general model regarding the growing internationalisation of world cities (Terhorst, 2005)?

The initial conditions of these cities were not so favourable to internationalisation as may have been expected. The overwhelming majority were industrial centres, serving mainly the needs of the domestic market and of the military. However, they proved to be much better adapted to market reforms and to post-industrial development than smaller towns. The relative diversity of their functions and a more highly skilled labor force have made them attractive for investment and have contributed to the rapid development of tertiary functions. They are, to a growing extent, affected by the process of economic internationalisation. It is therefore relevant to study emerging international functions of large regional Russian cities as new actors on the international political scene.

5 In this paper, we focus on political aspects of the internationalisation in large regional cities whose political elite has had to create a veritable international policy, in order to meet the needs of an opening urban society and to stimulate the economic growth as well. The goal of this paper is two-fold. First, we shall discuss a theoretical framework used to analyse the development of international functions in large regional centres and examine its appropriateness for studying the realities of large Russian cities. Secondly, we shall apply this approach to the cases of Yekaterinburg and Rostov.

6 The study is based on some results of an international comparative project (2003-2006) dedicated to the post-Soviet evolution of 11 major regional urban centres of the country (Novosibirsk, Nizhni-Novgorod, Yekaterinburg, Samara, Omsk, Kazan, Chelyabinsk, Rostov-on-Don, Ufa, Volgograd, Perm) ${ }^{1}$. The cities of Yekaterinburg (Urals) and Rostovon-Don (South) were choosed for in-depth research, because both of them, situated in different economic and cultural environments, have taken on, since 2000, the functions of federal district centres. A study of a city's international functions in Russia can result only from a field research because statistical data are extremely limited. Such research was conducted in February and September 2005 and included, in particular, dozens of 
interviews with regional and city officials and experts in each town (businessmen, academics, NGO representatives, etc.).

\section{Basic notions and approaches}

7 Many authors inspired by the pioneer book by Harvey (1989) have argued that growing internationalisation supposedly allowed a given city to ensure its future prosperity, in a world where classical location factors seemed to matter less than connectivity. Globalisation implies simultaneously deterritorialisation and reterritorialisation of economic space. Globalisation of production and capital is accompanied with the increasing role of place specific factors like geographical location, urbanisation economies, cultural and human capital accumulated in earlier historical periods, particular formal and informal structures of local economic regulation. Globalisation involves a necessary transition from centralised bureaucratic decision making to a plurality of networks and partnerships between government, businesses, and other nongovernmental agents. It also involved the rescaling of both economy and governance: the growing importance of the local and urban and the supra-national levels (such as European Union or the NAFTA). As a result, not only the capitals and the world cities but also regional centres gradually escape from the national regulation and compete for investments and capitals with similar places within the country and abroad, as is argued in the literature on global city networks (Sassen, 2002; Taylor, 2000, etc.). This process of rescaling known as "glocalisation" is related with the growing pressure to create more competitive local economies.

8 For this reason, political leaders are called upon to define and construct an international strategy to help cities improve their "competitiveness". This explains why city actors look abroad not only for investors and new markets, but also for efficient models of urban development, for inspiring cultural and societal experiments to possibly replicate. A variety of diverse parameters make up the life of large cities that are influenced by internationalisation and international actors - from finances to infrastructure, technical co-operation to "third sector" activity paradiplomacy, policy learning, and citizen involvement in urban governance. Numerous institutional possibilities exist, associating several political levels - from municipal to national: city to city (twin cities, etc.), city to international entity (agency, NGO, transnational company, etc.), city to international organisation via mediation by the country's political centre, or by a foreign city, or by a municipal association, etc. Each city has its own particular combination of such relationships, depending on many factors: the strength of the central state, the degree of decentralisation, the structure of the economy, the institutional organisation, etc. (Makarychev, 2000; Sluka, 2005).

9 Urban networks is one of the basic notions in the studies of world cities having by definition important international functions. Taylor (2005) distinguishes the following kinds of interactions: 1) inter-state being realized between or via the mediation of central governments; 2) supra-state operating above states; 3) trans-state operating across or beyond states without any participation of central governments. States determine a political space of places, while cities represent an economic space of flows. E. Shane (2005) defines urban networks as the conduits through which municipal and extramunicipal (regional, national and supranational) institutional and social relationships were negotiated, information exchanged, expertise and technical innovations 
disseminated and social capital realised. World cities competing with each other and inter-connected sometimes better than with other cities of their countries are supposed to be the main actors of globalization. Network processes are closely associated with globalization and challenge the reproduction of the Westphalian system of modern states (Scott, 2000). Taylor stresses that great cities can be interpreted as the organizational nodes of global governance and global society (Taylor, 2005, p. 706).

But P. Terhorst (2005) recently warned against an excessive focus on the study of the interplay between the global and the local levels, stressing that the national level still plays an extremely important role, with the central state as a key bargaining partner, even in local development policies. Terhorst also stressed that it was difficult to assume that all countries, regions and cities followed more or less the same trajectory in the transition from nationally embedded fordism towards glocalised post-fordism.

11 It is impossible to identify the involvement of regional centres in global networks without suggesting some parametres which could define the international activity of a city and its impact on its development. In case of Russia, do its regional centres really already compete with comparable foreign cities? Do they follow the general trajectory of internationalisation, to what extent it is specific and determined by national and regional factors? We propose to distinguish three groups of parameters for evaluating the intensity of a city's international activity:

a. Institutional co-operation

- foreign diplomatic and commercial representations in the city and representations of the given region abroad

- international agreements signed at all levels of power - from the central government to the municipality itself

- the size and importance of departments in charge of international contacts in the city's administration.

b. Activity

The second set of data includes information on permanent and temporary exhibitions and fairs with foreign participation, exchange of delegations, place marketing, tourism development policy.

c. Efficiency

This aspect is usually measured using quantitative parameters, such as: turnover of foreign trade; the number of joint ventures and foreign-owned companies as well as their contribution to GDP and employment; the number of international transportation facilities; and the number of facilities specific to the needs of resident communities of foreign officials and business leaders, etc., the involvement of the city in global and national productive and distribution networks.

12 It is very difficult to find reliable quantitative or qualitative variables allowing to provide a full comparative picture of Russian regional centres' international activity. In the following sections, we will focus mainly on some aspects of their institutional cooperation with foreign partners and indicators of its efficiency based on "hard" (statistics and documents) and "soft" (interviews) information that we found mainly during our field studies. But first we start with a description of general and specifically Russian factors of international activity. 


\section{Key factors for Russian regional capital's international activity}

\section{Historical heritage, geopolitical location and territorial diversity}

13 Two specific factors were determinant for Russian cities' international activity: the nature and the radical change of the political regime, and the extreme geographical, economic, social and ethnic diversity of the country. Other factors are not peculiar only to Russia but their impact is often strongly modified by a high polarization of territory.

Relations with foreign countries were controlled by the State for decades. Many large cities, the main foci of the military-industrial complex, including such major centres with over one million inhabitants as Nizhny Novgorod or Yekaterinburg, were closed to foreigners. As a result, they had little skilled staff prepared for co-operation with foreign partners and remained terra incognita abroad. The impact of the sudden opening of Soviet/Russian international boundaries in the late 1980s - the early 1990s on economy and society widely varied depending on the geographical location, historical traditions and cultural potential of large cities. In the far eastern part of the country, the formerly isolated city of Vladivostok (the main military port on the Pacific) became deeply involved in foreign trade, mainly with neighbouring China. The ratio of the trade turnover of the Maritime territory (Vladivostok is its centre) with China to the GDP is about $23 \%$. In the neighbouring territory of Khabarovsk it approaches $30 \%$. It means that China can impose an economic specialisation she needs (Kolossov and Borisova, 2007).

Several other cities situated near new post-Soviet boundaries managed to turn a previously problematic border location to their advantage, as was the case in Belgorod, which became a main trading and logistic centre between Russia and Ukraine. Due to it, the per capita trade with Ukraine in Belgorod region is the highest in Russia (Kolossov, 2002).

\section{Economic factors}

The prerequisites for international activity in Russian cities are strongly linked to their human capital and economic structure. It reflects the relationship between transnational, national and regional/local business and economic specialisation, which determines the involvement and the place of a city in international networks and its international competitiveness. Besides Moscow and Saint Petersburg, with their diversified postindustrial economy and rich human capital, or the main export areas (oil-and-gas cities or sea ports), only the large regional centres may be considered islands of globalisation (Zubarevich, 2005). They alone are able to develop a sufficient infrastructure (business facilities, services), adapted to the needs of an international activity.

\section{Urban Society and Culture}

17 A city's willingness to open itself up internationally is also determined by the political and social interests of individual groups articulated by political parties, social movements and lobbies. Therefore, internationalisation depends on a city's social and ethnic structure. Capitals of "ethnic" republics have particular premises for internationalization due to 
contacts with compatriots living in post-Soviet states and in other countries and/or with kin ethnic groups, like, for instance, Finnish-Ugrian peoples. The formation of immigrant communities also contributes to build international connections. Significant artistic and scientific activity transforms former industrial centres into "creative" cities (Florida, 2002), where the population develops intense international contacts. One may note, for instance, that the Russian scientific elite, concentrated mainly in the largest cities, succeeded in internationalising its activity during the 1990s, despite a spectacular crisis in state funding (Milard and Grossetti, 2006). Finally, the cities disposing of important historical and cultural heritage are normally more attractive for international tourism, which can be a powerful factor of urban transformations.

\section{Institutional roles of cities and regions} Moscow and Saint Petersburg, the subjects of the Russian Federation). The creation of 7 federal districts in May 2000 transformed the capitals of these districts into macroregional centres, improving the administrative centrality of Khabarovsk, Rostov, Novosibirsk, Yekaterinburg, Nizhny Novgorod and Saint Petersburg and attracting various foreign representative missions intended to serve a given part of the country. A great variety of institutional arrangements exist within regional administrations, but, in general, international activity lacks sufficient coordination.

As for municipalities, the new law on local self-government adopted in late 2003, which should be gradually implemented in 2006-2009, does not specify the areas for which they are responsible. It simply grants municipalities the right to establish international contacts (article 17, p. 8). But federal legislation developing this point does not exist yet. De facto, city authorities often co-operate with foreign diplomatic and business representations, joint ventures, and NGOs, helping them find a proper location for their activities and acting as mediators between foreign missions and the local milieu.

\section{Place marketing}

21 The construction and promotion of a city's image (place marketing) is a relatively new activity in Russian cities. It requires specific know-how and the help of PR agencies. Not all municipalities have realised the importance of image construction. Although most cities attempt to reinstate old traditions, fairs, holidays, historical monuments and other symbols, these efforts are rarely incorporated into a strategy not only encouraging domestic consumption, but also oriented toward a foreign target audience (tourists, 
businessmen). The lack of openness and of transparency in international activity matches the low interest of citizens to foreign contacts.

\section{International strategies}

The purposeful planning of international activity is characteristic of only the largest and most advanced cities, which take steps in order to define their objectives, key branches and geographical priorities and to avoid a chaotic exchange of delegations, or so-called bureaucratic tourism. An international strategy is usually an integral part of the urban strategic plan.

In the following sections we compare the influence of these factors on the development of the international activity of two large regional centres of Russia - Yekaterinburg and Rostov on the Don. They have comparable populations (1.32 mill. inhabitants in Yekaterinburg and 1.08 mill. in Rostov). In the early 1990s, Yekaterinburg may have appeared more vulnerable under market economy conditions as a result of its industrial structure, dominated by heavy machinery and metallurgy. A large part of its economy (research institutes and industry) belonged to the military-industrial complex. Rostov, on the other hand, apparently benefited from its geographical location in the south of the country, at the centre of a fertile agricultural area, close to the Black Sea resorts. Though it also became necessary to restructure its enormous machinery plants, such as Rostselmash, at that time the world largest producer of harvesting machines (in the 1980s it employed 55,000 people), Rostov's economic structure was more flexible - the production of consumer goods and food industry played a more important role, and there was more evidence of an entrepreneurial spirit. Unlike Yekaterinburg, the city has never been closed to foreigners. With this in mind, the questions arise: How have both cities adapted to this new context? How have their international functions developed?

\section{Yekaterinburg - Rostov: a comparative analysis of international activity}

\section{Historical heritage and location}

Both cities experienced a severe demographic crisis (natural decrease), compensated by an increasing inflow of immigrants. Rostov was one of few cities with over one million inhabitants, whose population increased between the 1989 and 2002 censuses, mostly due to the inflow of migrants from North Caucasus and Transcaucasia. Over the same period, Yekaterinburg lost several thousand inhabitants. The city's economy began to employ cheap labour from Kazakhstan and Central Asia, particularly in construction work. It is expected that, in the immediate future, immigration from Former Soviet Union countries and non-Russian areas in general will increase considerably (Vishnevsky, 2004), thereby diversifying the ethnic structure of such cities and contributing to the spontaneous internationalisation of city life.

Both Yekaterinburg and Rostov are situated in exceptional geographical locations. Rostov is located a few kilometres from the mouth of the Don and possesses a sea-river port open to ships coming from the Black Sea. It is also connected to the Volga-Don canal system. Finally, Rostov is the main railway hub in Southern Russia. It is situated in only 200-300 
$\mathrm{km}$ from the most developed regions of Ukraine. Yekaterinburg is situated in the main international transportation corridor which leads from Central Russia to the Far East and is the node of the Urals railway system. It has the largest number of direct railway connections of any big regional centre and is third in terms of the number of flights. It also has better direct international accessibility than Rostov (cf. Table 1).

Table 1. Centrality of 16 regional centres of Russia ${ }^{2}$.

\begin{tabular}{l|r|l|c}
\hline City & $\begin{array}{l}\text { Centrality (airways } \\
\text { communicatlons) }\end{array}$ & City & $\begin{array}{l}\text { Centrality (railways } \\
\text { communications) }\end{array}$ \\
\hline Novosibirsk & 147,5 & Yekaterinburg & 306 \\
\hline Samara & 143,25 & Perm & 228,5 \\
\hline Yekaterinburg & 106 & Rostov & 148,5 \\
\hline Krasnodar & 100 & Novosibirsk & 78,25 \\
\hline Ufa & 96 & Omsk & 68 \\
\hline Khabarovsk & 89,25 & Saratov & 67,375 \\
\hline Vladivostok & 84,25 & Volgograd & 56,75 \\
\hline Irkutsk & 79 & Cheliabinsk & 56,5 \\
\hline Krasnoyarsk & 75,25 & Ufa & 55,75 \\
\hline Rostov & 68 & Krasnoyarsk & 49,75 \\
\hline Volgograd & 51 & Kazan & 42,75 \\
\hline Cheliabinsk & 50,5 & Samara & 42 \\
\hline Omsk & 45,75 & Irkutsk & 33,5 \\
\hline Perm & 40,5 & Krasnodar & 30,5 \\
\hline Kazan & 39,5 & Khabarovsk & 17,55 \\
\hline Saratov & 14,5 & Vladivostok & 14 \\
\hline
\end{tabular}

\section{Economic factors}

Local experts estimate that in both Yekaterinburg's and Rostov's the non-regional capital controls 70 to $80 \%$ of GDP (mostly from Moscow). The purchase of a large taxpayer by a Moscow company often means that financial flows are diverted to its headquarter, which often provokes the resistance of regional governments. At the same time, economic rise of any region is impossible without external investments. Regional administrations try to get some benefits from large business and put different conditions to potential investors.

According to the estimations of the leading Russian consulting consortium "Expert RA AK\&M", the Sverdlovsk region (with Yekaterinburg at its centre) was fourth among 89 regions of Russia in terms of investment potential in 2004. The Rostov region also placed among the top regions but only in $12^{\text {th }}$ position.

This ranking has been confirmed by the international performance of the economy. Both regions and cities now contribute significantly to national foreign trade, but, once again, Yekaterinburg and its region come ahead (2:1 ratio). The Sverdlovsk region (foreign trade turnover in 2004: 6.2 billion dollars) runs fourth among the subjects of the Russian Federation. Moreover, its foreign trade is rapidly increasing: in 2004, it grew by $45 \%$ (the national average was $+27 \%$ ). In 2004, foreign companies invested 600 million dollars in the region's economy, mostly in the form of credit to large industrial holdings. The UK, Germany and the Virgin Islands are the leading investors (in the latter case, this means the repatriation of Russian capital, of course). The main export destinations (35\%) are Taiwan, the USA and the Netherlands. Ferrous and non-ferrous metals make up $60 \%$ of exports; chemicals, 20\%; machines and industrial equipment, $11 \%$.

Foreign trade turnover in the Rostov region is lower - about 3.2 billion dollars in 2004. The main trading partner is neighbouring Ukraine, constituting $31.3 \%$ of the total turnover (and not countries from "far abroad", as in the Yekaterinburg case). The city 
profited from large transit flows of goods, estimated at 930 million dollars (2003). Besides Ukraine, the main export destinations were Algeria, Greece, Italy, Turkey and Egypt; the bulk of imports came from Germany, Greece, Turkey, China and France. The Rostov region exports food products and agricultural raw materials (45\%); machines, industrial equipment and vehicles (24\%); and rolled metals (18\%).

The most difficult economic problem for both cities but especially for Yekaterinburg is the restructuring of the military-industrial complex and of large industrial plants, the development of small and medium business applying new technologies. The realization of this task is very capital consuming: the government of Sverdlovsk region estimates the yearly need in investments in 5 billion dollars: despite of the economic rise since 2000, it receives only 2.5 billion a year. Therefore, foreign investments and banks are very welcome.

\section{Urban society and culture, institutional roles of cities and regions}

31 According to sociological polls, Yekaterinburg's inhabitants see as its particularity the fact that it aspires towards a certain political autonomy from the central authorities. Historical traditions and a high level of education make Yekaterinburg culturally selfsufficient and able for innovations not depending on capitals. For Soviet/Russian and foreign musicians and artists going on tour over Russia Yekaterinburg has always been the third most prestigious destination after Moscow and Petersburg because of its educated audience. The city has nationally famous theatres and is origin of a number of well known musicians and rock bands (Sotsium, 2005).

The Sverdlovsk region traditionally is among the most liberal regions, while the Rostov region as a whole can be classified as an "average" or centrist region (Kolossov and Zubov, 1995; Belov, 2005), with a mixed political culture of personal freedom and ethnic diversity and tolerance, but also of a solid conservatism (the latter perhaps inherited from the Cossack culture).

The Moscow Centre of Carnegie Endowment for International Peace ranked the Sverdlovsk region (and respectively, Yekaterinburg as its major centre) first in Russia in their 2005 regional rating of the degree of democratisation ${ }^{3}$ (Petrov, 2005). Economic, social and political openness as well as democratisation are critically important conditions for the successful development of a region's international activity. Typically, the Rostov region has never reached the top ten in this rating.

Rostov, whose situation is not as favourable as that of Yekaterinburg, has beyond a doubt the best cultural infrastructure in the Southern federal district. Even though neighbouring Krasnodar comes close in certain fields, Rostov is far ahead in terms of education, research and culture (Vendina and Kolossov, 2004). Its image is related with the heritage of Ancient Greece and inter-cultural interactions (between Russians and Armenians, Ukrainians, Jews, etc.).

In terms of research, the trajectories of the two cities are also significantly different. Between 1992 and 2003, the Rostov region accounted for a stable 1.20\% of Russian scientific publications in international journals, while the amount produced by Yekaterinburg and Sverdlovsk oblast grew from $2.60 \%$ to $3.20 \%$ - a clear sign of successful internationalisation strategies. Yekaterinbourg can be identified as an up-and-coming 
major scientific centre, only behind Moscow, Petersburg and Novosibirsk (Milard and Grossetti, 2006).

Both Rostov and Yekaterinburg are now capitals of federal districts and accommodate the regional headquarters for a great number of federal agencies. For more than 14 years, Yekaterinburg has been the arena of a permanent political war between the mayor A. Chernetsky and the governor E. Rossel. Experts say that this never-ending competition is useful to the city and stimulates the elites. In Rostov, there were no serious conflicts between the governor and the mayor, nor between the main political institutions, but this situation did nothing to stimulate a dynamic international policy. Local conservatism has contributed to the creation of a milieu which seems to be less open to international initiatives.

\section{Place marketing}

Yekaterinburg authorities were among the first to realise the importance of a favourable image. They pay a great attention to its construction - still unusual even in large cities, except Moscow and Petersburg. The municipality created a PR agency called "Capital of the Urals", which plans out promotional campaigns, city symbols, slogans, etc.

This image-making policy is designed to promote several slogans. "Yekaterinburg is the third capital of Russia" (Moscow and Petersburg are traditionally called "the two capitals"). It means that the city does not live in the shadow of Moscow like most provincial cities west of the Urals and possesses an autonomous and outstanding cultural and scientific potential of international dimension.

Second, it is the capital of the Urals. Indeed, Yekaterinburg is certainly better located and equipped for this role than the two other largest cities - Cheliabinsk and Perm (Zotova, 2007) - and has become the administrative capital of the Urals Federal District. However, the superiority of Yekaterinburg is less evident in a number of fields - above all, in terms of its economy.

Third, Yekaterinburg also tries to sell its image as a city on the borderline between Europe and Asia (the boundary between Europe and Asia follows the watershed of the Ural Mountains, $40 \mathrm{~km}$ west of the city). This geographical particularity supposedly bears a wide variety of positive connotations: Yekaterinburg is a necessary link between continents, a tolerant city at the borders of two civilisations (Christian and Muslim, Slavic and Turcic, etc.). But a milestone erected in the 1860s on the road from Yekaterinburg to Moscow to mark the Eurasian border was located far from the city. It proved to be too difficult for the municipality to use this site as a tool to promote tourism or for its image construction. Eventually, the municipality made the decision to "re-locate" the boundary between continents and to build a new monument closer to the city and within its administrative territory. This new monument was the first step in the construction of a tourist complex, including various stores, souvenir shops, restaurants, etc. (Strategichesky proekt..., 2005).

41 Fourth, the promotion of the city is based on its image as a major site in Russia's tragic history: the place where the last tsar's family was assassinated in 1918. A large cathedral was recently (2003) built at the exact location of this event. It quickly became one of the main symbols of the city (Eckert, 2005). A monastery was also built in the woods, not far 
from the city, in the area where the remains of Nicolas II and his family were discovered in the late 1980s.

The development of such an active policy is quite impressive. As a result, $94 \%$ of the city's inhabitants and $87 \%$ of its visitors, according to a poll by Sotsium (2004), consider Yekaterinburg to be the capital of the Urals (cfr. table 2). Not surprisingly, 92\% of citizens do not like to leave it firmly, and only $2 \%$ liked to use the nearest opportunity to quit it.

Table 2. Reactions of the city's inhabitants, visitors and experts to the statement "Yekaterinburg is the capital of the Urals" (Sotsium 2004).

\begin{tabular}{l|c|c}
\hline Reactions & City's inhabitants & City's visitors \\
\hline Agree with it & 94,2 & 86,5 \\
\hline Believe it open to discussion & 4,2 & 8,0 \\
\hline Do not agree & 1,2 & 0,5 \\
\hline Difficult to say & 0,4 & 5,0 \\
\hline Total & 100,0 & 100,0 \\
\hline
\end{tabular}

All the same, changing popular representations and adapting them to the realities of a post-industrial urban economy means a lot of work for city leaders. For most respondents - both the city's inhabitants and visitors, Yekaterinburg still projects the image of a large industrial centre, one which, though still positive in the eyes of former Soviet citizens, is hardly compatible with the pretensions of a regional capital and its potential international role. For one thing, it would be difficult to promote such an image abroad.

Rostov is far behind Yekaterinburg in the promotion of a positive city image. Its recent Development Strategy includes not one paragraph about image construction (Strategichesky plan..., 2004). Nevertheless, this does not mean that there is no activity in this field or that authorities do not care at all about the image of Rostov. The main branding is more or less similar to that in Yekaterinburg and uses the same word "capital": "Rostov is the southern capital of Russia" and "Rostov is the capital of the Don". As the city stretches along the right bank of the Don, the river is becoming its main symbol. Its image is also closely tied to the history of the Don Cossacks, even though Rostov has never been their capital. There is no obvious international component in popular representations of Rostov.

\section{International strategies}

One of the main obstacles for the development of the international activity of both municipalities of Yekaterinburg and Rostov is the lack of funding. This problem has become critical in recent years due to re-centralisation and to the cities' growing financial and political dependence on regional and federal authorities.

The Strategic Plan of Yekaterinburg (Strategia..., 2003; Strategichesky..., 2003) appears more elaborate, socially oriented and concrete than the strategy of Rostov. It is the result of long discussions during sessions of the special council, which included not only public officials, but also representatives of the business community, the "third sector" and academic experts. The Yekaterinburg document announces the city's intention to become integrated into the world economy and to become a "multifunctional post-industrial centre with elements of a world city" (Strategichesky..., 2003, p.12). 

had no reliable or comprehensive information on its international role and contacts and only announced its intention to build up an overarching programme (Strategichesky..., 2004, p.212). The authors put forward the objective of creating an adequate urban environment and infrastructure for international business. Before the adoption of this plan, the municipality's official international activity was limited to cultural relations and contacts with twin cities.

\section{The results and efficiency of internationalisation policies in Yekaterinburg and Rostov}

\section{Inter-state activities}

Eight general consulates work in Yekaterinburg (USA, Great Britain, Germany, Czech Republic, Azerbaijan, etc.). Four new consulates should open in 2006, and authorities expect there to be 17 consulates in the city before the end of this decade. This is, of course, to a large extent a result of the role of Yekaterinburg as the centre of a federal district: all consulates serve the Urals as a whole. The Sverdlovsk region has a single representative mission abroad, located in the Netherlands.

The inter-state activity of Rostov is significantly more modest: it accommodates the consulates of Armenia and of neighbouring Ukraine (there is a large Ukrainian minority in the region, and $40 \%$ of Rostov's inhabitants have family in Ukraine). Two other countries of the Black Sea basin plan to open their consulates in Rostov: Bulgaria and Romania.

The Yekaterinburg municipality has decided to concentrate its efforts on relations with a selected panel of twin cities: Guangzhou (China), Genoa, Birmingham and Frankfurt. Guangzhou maintains intense trade relations with Yekaterinburg. Co-operation with European twin cities focuses on the realisation of social programmes (for instance, "Talented children" and "Family" with Birmingham), as well as on the promotion of the positive image of Yekaterinburg. Regular business missions travel in both directions. The municipality has established particularly good relations with the British Consulate, which participated in its co-operation with Birmingham as well as in discussions on the Strategic Plan.

51 Yekaterinburg tries to become the "capital of regional capitals". This political task strengthen the positions of the Yekaterinburg's mayor A.Chernetsky, who chairs the Association of Russian Cities, and matches his official claim to make the city the third national capital. Every two year the municipality of Yekaterinburg helds a conference of all Russian cities with more than one million dwellers (except Moscow and Petersburg).

\section{Trans-state activities}

Approximately 200 branches of foreign companies are now active in Yekaterinburg, including those of the Dresdner Bank and the Raiffeisen Bank. Many joint ventures are being undertaken, The consulting agency Ernst and Young has been active in the city since 1997. Every year, 20 new representative missions or branches of foreign companies are 
registered, and the city ranks third in terms of the number of foreign diplomatic and commercial representative offices, after Moscow and Saint Petersburg.

One of the most obvious manifestations of globalisation is the development of international distribution (sales) networks. National and international networks are currently booming in Russia. The rapid expansion of hyper- and supermarkets is particularly impressive. Yekaterinburg has developed this kind of retail trade much more quickly than Rostov. Many international brands are already represented on the markets of both Yekaterinburg and Rostov: Baskin and Robbins, Rostiks, Subway, Naf-Naf, Zara, H \& M and many others. Despite the generally greater willingness of Yekaterinburg to open up to external influence, it seems that Rostov authorities and local businesses are more accepting of Moscow-based and foreign retail trade networks. It took, for instance, many months for the Yekaterinburg authorities to agree to the opening of Metro (2005) and IKEA (2006). Besides Moscow and Petersburg, by late 2004 only Novosibirsk was ahead of Yekaterinburg by the number of stores belonging to networks, while Rostov was the tenth (figure 1). As a city with a relatively high per capita income, Yekaterinburg, as well as other large cities situated eastward from Moscow (Nizhny Novgorod, Samara, Perm, Ufa) was one of the first destinations for Moscow, Petersburg and foreign companies expanding in the province.

Figure 1. The largest cities of Russia.

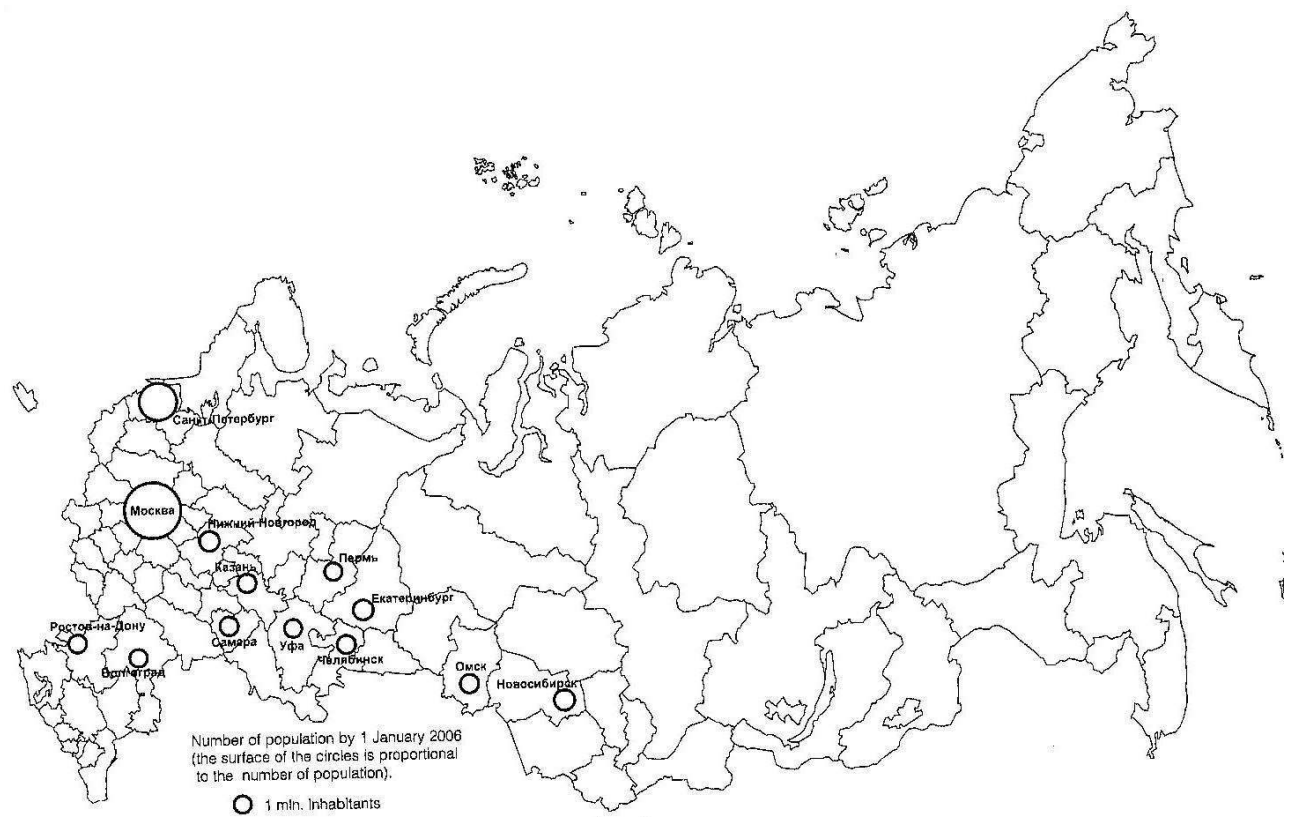

A great number of international organisations have focused their activity on Yekaterinburg, a city formerly closed to such intervention. Its administration has been actively supporting and participating in international projects since 1992 (funded by US Aid, USIA, TACIS, the Know How Foundation, etc.). American aid, in particular, was granted to support the construction of condominiums. Altogether, the municipality participated in more than 50 large-scale projects. Several NGO's that were created temporarily as a result of these projects have continued their activity as municipal or independent institutions (Centre for Energy-Saving, Centre of Environmental Education, Centre for Civil Initiatives, etc.). The work on international projects shaped a community thinking in a new way and prepared for international cooperation. 
Rostov is also involved in such activity with 27 foreign branches of international organisations and projects: in particular, TACIS, the Global Environmental Foundation, the "Eurasia" Foundation. IBRD, for example, supported a programme for renovating real estate for the city's health care and educational system, completed in 2003.

An important element of Yekaterinburg's international ambitions is making the city "a meeting point for consumers and producers" and to transform it in a centre for frequent exhibitions and conferences. The city hosts international events, though its possibilities are limited for the moment by its inadequate infrastructure. Plans currently exist to build an international exhibition complex at the entrance to the city, near the Koltsovo airport, itself under reconstruction. A project is also underway for an international conference centre able to seat 3,000. The city bears special hopes in its partnership with Italian municipalities and companies (in particular, from its twin-city of Genoa). They works out the project of the so called Italian bloc, which will include small shoes and furniture plants, fashion centres, storage capacities, hotels and housing. In addition, plans exist to build the first part of the so-called Yekaterinburg City (a business district) around the Hyatt Hotel. 35 hotels should be built in 2006-2010, and international networks like Accor, Park Inn, and Mariott are expected to arrive. These ambitious projects are based on the booming oil and gas industry in the neighbouring regions of West Siberia, now a part of the Urals Federal District. Their financial resources stimulate economic activity in the city, especially in the very speculative real estate market.

There are no large new hotels and conference centres in Rostov. Local experts believe that new small, one to three star, private hotels and renovated old hotels suffice. On average, 41 to $45 \%$ of rooms are occupied, which is considered a satisfactory result (the national average is $38 \%$ ) (Dolzhenko, 2005).

Figure 2. Trading networks in the largest regional centres of Russian Federation by origin (except Moscow and Saint Petersburg) ${ }^{5}$.

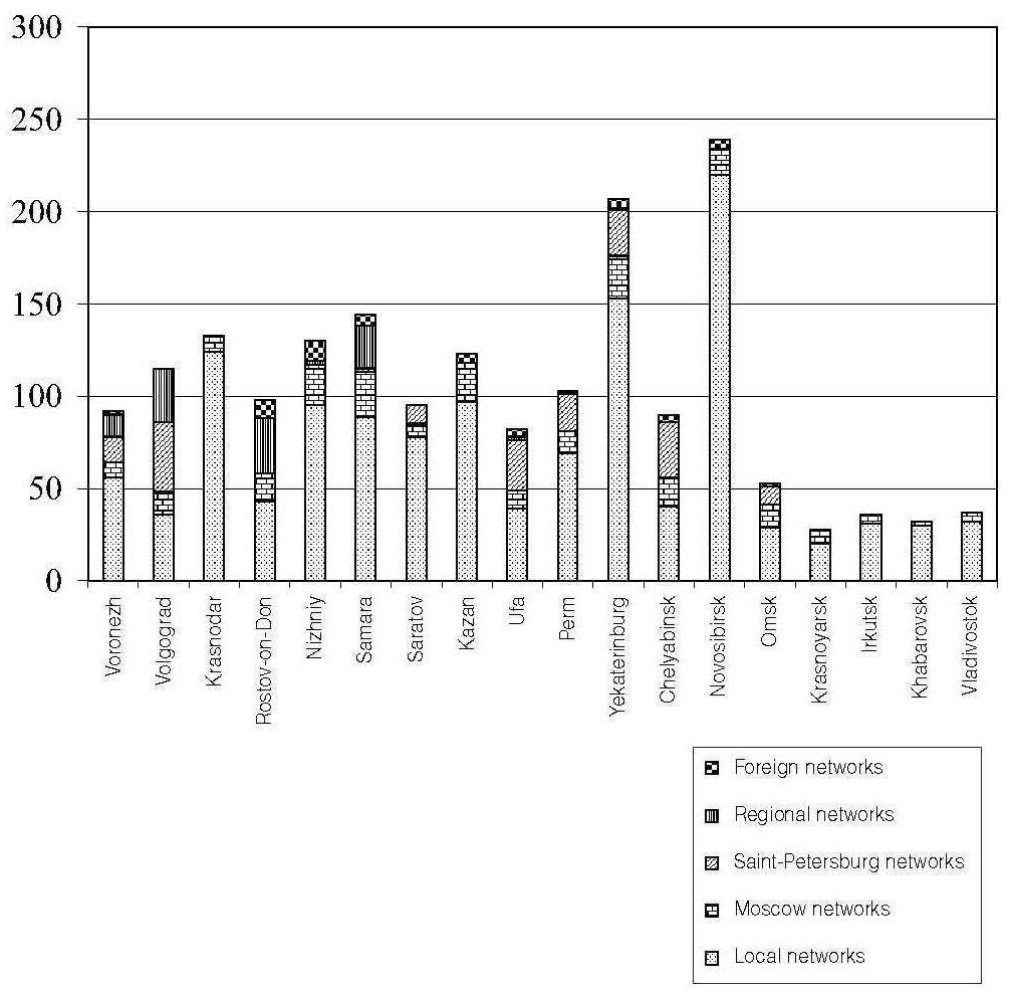




\section{Conclusion}

Starting from almost nothing fifteen years ago, Russian metropolitan centres have become highly involved in international contacts, yet the various cities now find themselves in very different stages. It is thus necessary to distinguish between the objective processes of globalisation, leading to the internationalisation of urban economies, and the purposeful policy-making of local authorities in the hope of improving their cities' international status, to use them more efficiently as a resource of the socio-economic development. Municipal policy varies greatly from one large city to another. Unlike Yekaterinburg, Rostov's authorities have not yet worked out an efficient international strategy and have not fully realised its systemic character and significance.

A comparison of Yekaterinburg and Rostov demonstrates that cultural factors of internationalisation are equally as important as economic restructuring. In the early 1990s, Yekaterinburg and Rostov had similar prerequisites for becoming involved in international economic and cultural relations, but the city in the Urals managed to exploit them more thoroughly due both to its more open, competitive and democratic governance and to its more diverse and qualified human capital.

The involvement of Russian regional centres in globalisation is still relatively week as compared with the cities of the same rank in West Europe or North America. It can be explained by the recent Soviet past but also by the size of the country. Even the cities with over one million inhabitants assume mostly intra-regional functions within the administrative boundaries of the regions they are the centres. This is also certainly a result of a high political centralisation. Since 2000 Russia is experiencing a new wave of re-centralisation officially aimed to restore the governance and the priority of the federal legislation over regional laws. Moscow has always been suspicious toward the activity of regional and urban governments on the international scene. The same tendency is reproduced at the regional level, in the relations between governors and mayors of large cities. Respectively, the central state has by far more bargaining power in relations with foreign economic and other partners than a region or a city. We did not find obvious evidences of a real competition of Russian regional centres with foreign cities. At least, most municipalities do not participate yet directly in this competition. In this part of the world, it can be hardly presumed that transnational relations are gradually replacing the classical Westphalian model of international links. It confirms the conclusion of $\mathrm{P}$. Terhorst that there is no general model of globalisation and its trajectories are very different.

\section{BIBLIOGRAPHY}

BEAVERSTOCK J.V., SMITH R.G. \& TAYLOR P.J. (1999), “A Roster of World Cities”, Cities, 16, 6, pp. 445-458. 
BELOV A. (2005) Faktory territorialnoi differentsiatsii elektoralnogo povedenia naselenia Rossii (Factors of the territorial differentiation of the electoral behaviour of Russian population), Doctoral thesis. Moscow, Faculty of Geography, Moscow State University.

DOLZHENKO G.P. (2005), “Turizm v Donskom regione (Tourism in the Don Region)”, Trudy Akademii turizma, 6, pp. 123-133.

ECKERT D. (2004), Le Monde russe, Paris, Hachette.

ECKERT D. (2005), “Un nouveau haut-lieu commémoratif en Russie :

l'Église sur le Sang Versé d'Ékatérinbourg”, Mappemonde, 77, 1, http://mappemonde.mgm.fr/ actualites/ekaterinbourg.html.

FLORIDA R. (2002), The rise of the creative class and how it's transforming work, leisure community and everyday life, New York, Basic Books.

HARVEY D. (1989), The Condition of Post-Modernity, Oxford, Basil Blackwell.

KOLOSSOV V. (2002), Internationalization or Adaptation? Historical Legacy, Geopolitics and Border Cooperation in Belgorod Oblast. Regionalization of Russian Foreign and Security Policy, Working Paper, 15 , Zurich, Swiss Federal Institute of Technlogy.

KOLOSSOV V.A. \& BORISOVA N.A. (2007, forthcoming), Mezhregionalnoe i prigranichnoe sotrudnichestvo mezhdu Rossiei i Kitaem kak faktor uvelichenia tovarooborota (Inter-Regional and Crossboundary Cooperation between Russia and China as a mean to increase the turnover of trade), Mir peremen.

KOLOSSOV V. \& VENDINA O. (1997), Moscou : Retour à la Route Mondiale - Métropolisation et Politique, sous la direction de Paul Claval, Paris, L'Harmattan, pp. 135-153.

KOLOSSOV V. \& ZUBOV A. (1995), "Value Orientations of Russian Voters”, Russian Politics and Law, 3,5 , pp. 25-58.

KOLOSSOV V. \& O'LOUGHLIN J. (2004), "How Moscow is becoming a capitalist mega-city", International Social Science Journal, 181, pp. 413-428.

LEFEVRE C. (2005), Paris, an international strategy, Paper submitted to CITTA-ESF meeting, Zürich.

MAKARYCHEV A.S. (2000), Islands of Globalization: Regional Russia and the Outside World, Regionalization of Russian Foreign and Security Policy, Project organized by The Russian Study Group at the Centre for Security Studies and Conflict, Research, Working paper, 2, Zürich, Eidgenössische Technische Hochschule, 58 p.

MILARD B., GROSSETTI M. (2006), "L'évolution de la recherche scientifique dans les régions de Russie : déclin ou déconcentration ?”, Mappemonde, 81 , http://mappemonde.mgm.fr

O'LOUGHLIN J. \& KOLOSSOV V. (eds.) (2002), “Moscow as an Emergent World City”, Special Issue of Eurasian Geography and Economics, 23, 3, pp. 161-270.

PETROV N. (2005), Demokratichnost' regionov Rossii (Degree of democracy development in the regions of Russia), Moscow Centre of Carnegie Endowment for International Peace, Briefings, 7, 9.

SASSEN S. (ed.) (2002), Global Networks, Linked Cities. Routledge, N.Y.

SHANE E. (2005), The history of city networking: a Birmingham tale, Paper submitted to CITTA-ESF meeting, Zürich.

SLUKA N.A. (2005), Gradotsenticheskaya model' mirovogo khoziaistva (An Urban Model of World Economy), Moscow, Press-Solo, $167 \mathrm{p}$. 
SOTSIALNO-EKONOMICHESKII PASPORT ROSTOVA (Socio-Economic Passport of Rostov) (2005), http://www.rostov-gorod.ru/index/docs/mms:/phpBB2/index.php?id=2409

SOTSIUM. DATA OF SURVEYS (2004), Personal communication, interview with Dr. Olga Rybakova, director of the Urals Regional Foundation of Socio-Economic studies "Sotsium”, February 16, 2005.

Strategia razvitia krupneishego goroda: vzgliad $v$ budushchee (The Strategy of the Development of a Large City: A View to the Future) (2003), Yekaterinburg, Uralsky rabochii, 455 p.

Strategichesky plan Yekaterinburga (The Strategic Plan of Yekaterinburg) (2003), Municipality of Yekaterinburg, $192 \mathrm{p}$.

Strategichesky plan sotsialno-ekonomicheskogo razvitia goroda Rostova-na-Donu (The strategic Plan of the Development of the city of Rostov on the Don) (2004), Rostov, Infoservice.

Strategichesky proekt "Granitsa mezhdu Evropoi i Aziei" (The Strategic Project "The Boundary between Europe and Asia") (2005), http://ekburg.ru/adm/adm/255_40706_0_1

TAYLOR P.J. (2000), “World Cities and Territorial States Under Conditions of Contemporary Globalization”, Political Geography, 19, 1, pp. 5-32.

TAYLOR P.J. (2005), "New political geographies: Global civil society and global governance through world city networks”, Political Geography, 24, 6, pp. 703-730.

TAYLOR P.J. \& HOYLER M. (2000), “The Spatial Order of European Cities Under Conditions of Contemporary Globalization”, Tidjschrift voor Economische en Sociale Geografie, 91, 2, pp. 176-189.

TERHORST P. (2005), On the Articulation of Sectoral Policy Networks and Urban Development Strategies: the Strengtheing of Amsterdam as a Gateway to Europe, Paper submitted to CITTA-ESF meeting, Zürich.

VENDINA O. \& KOLOSSOV V. (2004), “Gde nakhoditsia stolitsa Rossii?” (Where is the capital of Russia's South?), Politia, 2 (33), pp. 52-78.

VISHNEVSKY A. (2004), "Demograficheskoe budushchee Rossii” (The Demographic Future of Russia), Otechestvennye zapiski, 4, pp. 131-149.

ZOTOVA M.S. (2007, forthcoming), "Stolitsa Urala : odna ili tri ?" (The Capital of Urals: One or Three?), Social-Political Studies.

ZUBAREVCH N. (ed.) (2005), Rossia regionov: $v$ kakom sotsialnom prostranstve my zhivem? (Russia of regions: in What Social Space Do We Live?), Moscow, Independent Institute of Social Policy.

\section{NOTES}

1. This paper reports the results of two projects: 1) "Large cities and metropolisation in Russia and Western Europe" supported by the French National Centre for Scientific Research. Grant reference: PICS 2098; 2) "Large Cities of Russia: Potential for Development and Competition for Inter-regional Influence" supported by the Russian Foundation for Social Sciences. Grant reference: N 04-02-00168a. Both projects were backed by collaboration within a special international network which included the Centre for Geopolitical Studies, Moscow (Russian Academy of Science); Interdisciplinary Centre for Urban Studies, Toulouse (CNRS); Centre for Municipal Economy, Yekaterinburg (State Economic University; Centre for Regional Policy, Rostov (State University). The authors express their gratitude to their colleagues Pr N. Vlasova (Yekaterinburg) and Pr A. Druzhinin (Rostov). 
2. The calculation took into account: 1) international travel (direct flights and trains to foreign cities); 2) national centripetal travel (flights and trains to Moscow); 3) inter-regional first-rank travel (flights and trains to other cities situated outside the respective federal district, except Moscow); 4) inter-regional second-rank travel (flights and trains to the cities situated in the same federal district, but outside the respective region); 5) intra-regional travel. The number of flights and direct trains in each category was weighted: the number of connections in the first category was multiplied by 1.5 ; in the second category, by 1 ; in the third category, by 0.75 ; in the fourth category, by 0.5 ; and in the fifth category, by 0.25 . The index represents the sum of these weighted variables. Data were collected from current schedules by M. Goryunova.

3. This index was calculated via the point-based evaluation of a series of variables describing: 1) the regional balance of power, the autonomy of the judicial system?, violations of civil rights, etc.; 2) the accessibility and diversity of political life; 3) electoral procedures; 4) political pluralism; 5) the autonomy of the mass media; 6) corruption; 7) economic liberalism; 8) the development of civil society; 9) the quality and rotation of the political elite; and 10) the autonomy and activity of local governments.

4. The three major cities of the Southern federal district are Rostov, Volgograd and Krasnodar.

5. Source: Zotova M.S. (2007) Krupnye goroda RF kak tsentry razvitia otechestvennykh i inostrannylh setevykh struktur (Large Cities of Russian Federation as Centres of the Development of National and Foreign Networks). Izvestia Rossiiskoi Akademii nauk, ser. Geograficheskaya, 2007, N 1.

\section{ABSTRACTS}

The authors consider theoretical approaches to the evaluation of international functions of large regional centres. They analyse the factors determining this activity and propose a number of quantitative and qualitative indicators helping to estimate its efficiency. A special attention is paid to the role of local governments in the development of foreign contacts. It is shown that Russian metropolitan centres have become highly involved in international contacts, but they find themselves in very different stages. A comparison of Yekaterinburg and Rostov demonstrates that cultural factors of internationalisation are as important as economic restructuring.

Les auteurs examinent les approches théoriques de l'évaluation des fonctions internationales des grands centres régionaux. Ils en analysent les facteurs déterminants et proposent certains indicateurs, tant quantitatifs que qualitatifs, pour évaluer leur efficience. Une attention particulière est accordée au rôle des gouvernements locaux dans le développement de contacts extérieurs. Les auteurs démontrent que les centres métropolitains en Russie sont aujourd'hui très impliqués dans les contacts internationaux, bien qu'à des stades très différents. Une comparaison de Yekaterinburg et Rostov montre que les facteurs culturels d'internationalisation ont autant de poids que les restructurations économiques. 
INDEX

Keywords: large regional centres, international activity, Russia, approaches, measurement, factors, efficiency, trajectories of globalisation

Mots-clés: grands centres régionaux, activité internationale, Russie, approches, évaluation, facteurs, efficience, trajectoires de mondialisation

\section{AUTHORS}

\section{VLADIMIR KOLOSSOV}

Centre of Geopolitical Studies, Institute of Geography, Russian Academy of Sciences, vladk@online.ru

\section{DENIS ECKERT}

Interdisciplinary Centre for Urban Studies, CNRS/University of Toulouse-le Mirail, eckert@univtlse2.fr 